\title{
Analisis Sistem Injeksi Air/Metanol dan Air/Etanol Terhadap Konsumsi Bahan Bakar dan Emisi Gas Buang
}

\author{
Jalyiamsep Marbun ${ }^{1, a)}$, Dahmir Dahlan ${ }^{2, b)}$ \\ 1,2 Program Studi Magister Teknik Mesin, Fakultas Teknik, Universitas Pancasila \\ Jl. Borobudur, No.07, Cikini, Menteng, Jakarta Pusat, DKI Jakarta, Indonesia, 10320 \\ a)jalyiamsepmarbun@gmail.com (corresponding author), ${ }^{\text {b) }}$ dahmir@univpancasila.ac.id
}

\begin{abstract}
Abstrak
Pengembangan mesin otomotif masa depan adalah bagaimana menemukan solusi untuk mengurangi emisi gas buang yang dihasilkan dan konsumsi bahan bakar yang lebih hemat. Telah banyak dilakukan berbagai penelitian dengan tujuan untuk mengurangi emisi gas buang dan konsumsi bahan bakar salah satu yang banyak diminati adalah dengan menggunakan sistem injeksi air. Sistem injeksi air langsung maupun tidak langsung mampu menurunkan emisi gas buang serta konsumsi bahan bakar dengan pemilihan konstruksi dan posisi sistem injeksi air yang tepat. Sistem injeksi tambahan air/metanol dan air/etanol digunakan untuk memaksimalkan sistem injeksi yang hanya menggunakan air yang sulit menguap. Metode yang digunakan pada penelitian ini adalah metode eksperimen dengan menguji sampel campuran air/metanol atau air/etanol dan mengumpulkan data uji coba kemudian melakukan analisis data konsumsi bahan bakar dan emisi gas buang. Hasil penelitian menunjukan emisi gas buang mengalami penurunan nilai HC yang cukup signifikan pada sampel AE10 sebesar $90 \%$, gas $\mathrm{CO}$ juga berkurang sebesar $69,7 \%$ dan $\mathrm{CO}_{2}$ berada pada nilai $14,50 \%$ dan AFR yang berada pada angka 14,7:1. Konsumsi bahan bakar meningkat seiring peningkatan perbandingan $\mathrm{H}_{2} \mathrm{O}$ atau air pada campuran. Namun dengan peningkatan konsumsi bahan bakar tidak membuat emisi gas buang juga meningkat dengan menggunakan sistem injeksi AM dan AE.
\end{abstract}

Kata kunci: injeksi air/metanol, injeksi air/etanol, water injection system, konsumsi bahan bakar

\begin{abstract}
The development of future automotive engines is how to find solutions to reduce exhaust emissions produced and fuel consumption more efficiently. Many studies have been carried out with the aim of reducing exhaust emissions and fuel consumption, one of which is the use of a water injection system. Direct and indirect water injection systems can reduce exhaust emissions and fuel consumption by choosing the right construction and position of the water injection system. Additional water / methanol and water / ethanol injection systems are used to maximize injection systems that only use water that is difficult to evaporate. The method used in this research is an experimental method with a sample test of a mixture of water / methanol or water / ethanol and collects trial data and then analyzes data on fuel consumption and exhaust gas emissions. The results showed that exhaust gas emissions decreased significantly in the HC value of the AE10 sample by $90 \%$, gas CO was also reduced by $69.7 \%$ and $C O 2$ was at a value of $14.50 \%$ and AFR was at 14.7: 1. Fuel consumption increases as the ratio of $H 2 \mathrm{O}$ or water to the mixture increases. However, the increase in fuel consumption does not increase exhaust emissions by using the AM and AE injection systems.
\end{abstract}

Keywords: water/methanol injection, water/ethanol injection, water injection system, fuel consumption

\section{PENDAHULUAN}

Saat ini penggunaan bahan bakar fosil untuk kendaraan semakin meningkat seiring populasi kendaraan yang semakin banyak terkhusus diperkotaan. Jumlah kendaraan berbanding lurus dengan emisi gas buang yang dihasilkan serta juga meningkatkan penggunaan bahan bakar pada kendaraan. Hal ini merupakan isu yang sangat menarik bagi peneliti untuk melakukan penelitian dan mencari solusi yang tepat bagaimana cara terbaik untuk mengurangi dampak negatif yang dihasilkan. Polusi udara yang mengakibatkan pemanasan global, peningkatan suhu dan akan terjadinya kelangkaan bahan bakar dimasa depan. Hal ini yang harus pemerintah dan para peneliti mulai pikirkan untuk mengurangi dampak buruk ini dengan menciptakan berbagai inovasi dan teknologi tepat guna untuk mendapatkan solusi yang terbaik.

Perkembangan teknologi pada mesin otomotif akan menjadi salah satu solusi untuk mengurangi dampak polusi udara dibeberapa negara dengan jumlah kendaraan yang tinggi. Hal ini membuat perkembangan teknologi pada kendaraan menuju kearah ramah lingkungan mulai diminati. Seperti dengan penggunaan teknologi injeksi pada kendaraan, berbagai aturan yang dikeluarkan oleh pemerintah dengan melakukan uji emisi kendaraan dan membuat ambang batas emisi gas buang yang semakin tinggi mengharuskan produsen kendaraan berinovasi untuk melewati ambang batas yang telah ditentukan.

Beberapa negara melakukan aturan dengan menambahkan bahan bakar nabati seperti metanol atau etanol dicampurkan dengan bahan bakar fosil untuk mendapatkan hasil yang maksimal dan lebih ramah lingkungan. Jenis campuran yang diberikan dengan berbagai perbandingan variasi antara bahan bakar fosil dan nabati. Diharapkan dengan campuran ini mendapatkan pembakaran yang lebih sempurna sehingga menghasilkan emisi gas buang yang 
seminimal mungkin sehingga dapat mengurangi dampak lingkungan. Namun penambahan langsung ke bahan bakar memiliki batas maksimal campuran karena bahan material kendaraan tidak dibuat khusus untuk bahan bakar methanol ataupun etanol dengan jumlah campuran yang banyak. Hal ini dapat menyebabkan terjadinya korosi dan kerusakan pada beberapa komponen mesin.

\section{LANDASAN TEORI}

Salah satu inovasi yang mulai berkembang dan dilakukan penelitian saat ini adalah penggunaan sistem injeksi air pada kendaraan untuk mengurangi emisi gas buang. Sistem injeksi air juga dikenal sebagai injeksi anti-detonant adalah metode untuk mendinginkan ruang pembakaran mesin dengan menginjeksikan air ke ruang silinder, umumnya bertujuan untuk meningkatkan rasio kompresi dan menghilangkan masalah ketukan[1]. Dengan meningkatnya suhu didalam ruang bakar juga semakin meningkatnya kemungkinan terjadinya knocking pada mesin. Bosch yang mengembangkan teknologi ini, menawarkan sistem injeksi air yang diberi nama WaterBoost untuk pabrikan lain. Perusahaan mengklaim kenaikan kinerja mesin sebesar 4\%, penurunan emisi $\mathrm{CO}_{2}$ hingga $4 \%$ dan peningkatan penghematan bahan bakar sebesar 13\% [2]. Rasio optimal injeksi air pada angka $15 \%$ dengan massa bahan bakar, hal ini menghasilkan peningkatkan performa dan emisi mesin (termasuk $\mathrm{NOx}, \mathrm{CO}_{2}, \mathrm{HC}$ dan jelaga) emisi NOx mengalami penurunan sebesar 34,6\% [3]. Dengan sistem injeksi air dan jumlah rasio yang tepat dapat meningkatkan performa mesin dan menurunkan emisi gas buang. Sistem injeksi ini menyuntikkan campuran air yang diubah menjadi bentuk kabut ke ruang bakar agar terjadi pembakaran yang sempurna sehingga mengurangi gas emisi yang berbahaya. Efisiensi bahan bakar dengan injeksi air meningkat hingga 20\% ketika mesin dioperasikan pada saat throttle valve terbuka penuh. Pada saat yang sama peningkatan daya lebih dari $4 \%$ dicapai dibandingkan dengan operasi tanpa injeksi air [4].

Berbagai jenis sistem injeksi air dengan model yang bervariasi diantaranya adalah sistem injeksi air tidak langsung dengan menggunakan jenis mesin direct injection system. Kemudian model sistem injeksi air dengan injeksi langsung ke ruang mesin dan menggunakan jenis mesin direct injection menunjukkan hasil kinerja mesin meningkat karena peningkatan tekanan dan efisiensi efektif yang ditunjukkan dari hasil pendinginan bagian-bagian mesin tertentu. Injeksi air juga menunjukkan penurunan emisi gas buang kendaraan [3]. Model sistem injeksi air dengan injeksi air langsung dan menggunakan mesin indirect injection menunjukkan hasil bahwa penambahan injeksi air mengurangi kemungkinan terjadinya ketukan pada beban mesin di torsi $90 \mathrm{Nm}$ dan pada kondisi kecepatan mesin 2000 rpm dan waktu percikan busi yang maju juga dapat langsung meningkatkan Break Specific Fuel Consumption [5]. Model sistem injeksi air tidak langsung dan menggunakan mesin indirect injection dengan sistem ini menunjukkan efisiensi bahan bakar dengan injeksi air tidak langsung dapat meningkat hingga 20\% ketika mesin dioperasikan pada saat throttle valve terbuka penuh. Pada saat yang sama peningkatan daya lebih dari 4\% dicapai dibandingkan dengan operasi tanpa injeksi air[4]. Eksperimen yang dilakukan oleh Durst menunjukkan bahwa injeksi air di intake manifold dengan rasio bahan bakar air hingga $50 \%$ dapat menurunkan emisi NOx hingga 25\% pada kecepatan rendah dengan beban parsial, sedangkan emisi NOx meningkat secara terus menerus dan mencapai empat kali pada saat beban penuh dan kecepatan tinggi [6].

Beberapa sistem injeksi menggunakan injeksi air langsung ataupun tidak langsung ke dalam ruang bakar menunjukkan beberapa manfaat langsung, baik kenaikan daya atau torsi juga menurunkan emisi gas buang serta konsumsi bahan bakar. Indicated Specific Fuel Consumption memiliki tren kebalikan dari Idicated Mean Fuel Consumption yaitu menurun, dan kemudian mencapai titik minimum pada rasio W/F 0,6 dan kemudian meningkat dengan peningkatan rasio $\mathrm{W} / \mathrm{F}$. ISFC pada rasio W/F 0,6 adalah sekitar $243 \mathrm{~g} / \mathrm{kW}$ jam, yang sekitar $8,2 \%$ lebih rendah daripada tanpa injeksi air [7].

Proses penguapan air didalam ruang bakar akan membentuk hidroksida dan hidrogen pada suhu tinggi, yang menyerap panas selama pembakaran. Uap air tidak hanya menyerap panas untuk menurunkan suhu, tapi juga menyediakan oksigen untuk membakar bahan bakar dan menyebabkan emisi NOx yang lebih rendah. Di bawah kondisi yang sesuai, penguapan air dapat mengakibatkan pendinginan, dan karenanya, meningkatkan kepadatan campuran bahan bakar-udara masuk sebelum penutupan katup masuk [8]. Namun dengan menurunnya suhu ruang bakar karena melakukan injeksi air menyebabkan gas $\mathrm{CO}_{2}$ meningkat seiring peningkatan jumlah injeksi air. Untuk memberikan solusi lain dan memaksimalkan keseimbangan emisi gas buang antara $\mathrm{NO}_{\mathrm{X}}$ dengan $\mathrm{CO}_{2}$ beberapa peneliti mencampurkan air dengan metanol atau etanol. Hal ini bertujuan untuk mengatasi kesulitan penguapan pada air.

Manfaat potensial lain dari injeksi campuran air/metanol atau air/etanol dari pada injeksi hanya air adalah laju penguapan yang lebih cepat dari yang diharapkan. Hal ini merupakan perspektif yang menarik untuk mengatasi kesulitan penguapan yang dialami oleh injeksi air pada kondisi RPM rendah [9].

Pada penelitian ini sistem diaplikasikan ke mesin piston tunggal dengan sistem injeksi di intake manifold dan menambahkan campuran air dengan metanol atau etanol untuk menghasilkan pembakaran yang lebih sempurna dan emisi gas buang yang rendah. Dengan penambahan metanol atau etanol pada injeksi air diharapkan mendapatkan efek yang lebih maksimal dalam proses pembakaran. Serta diharapkan dapat menjadi solusi pada sistem injeksi air yang sulit menguap pada putaran bawah [9]. Hasil percobaan pada mesin biodiesel turbocharged yang dilakukan oleh Tesfa menunjukkan bahwa air yang diinjeksikan ke dalam intake manifold mengurangi emisi NOx hingga 
$50 \%$ di seluruh rentang operasi. Namun, emisi gas CO meningkat sekitar $40 \%$ [10].

Karakteristik emisi dan performa mesin sangat tergantung pada karakteristik penguapan air dan rasio air terhadap bahan bakar yaitu 0,6 dengan jumlah lubang nosel 6 dan diameter nosel $0,14 \mathrm{~mm}$ menghasilkan tekanan efektif rata-rata tertinggi dan emisi NOx, jelaga, dan CO terendah dibandingkan dengan kasus tanpan injeksi air [7].

Kualitas atomisasi primer yang pada akhirnya bergantung pada desain nosel dan tekanan injeksi, merupakan poin penting untuk meningkatkan kinerja sistem WI. Lokasi dan posisi injektor air juga sangat penting [11]. Hal ini menunjukan bahwa sistem injeksi ini dapat bekerja maksimal dengan cara mengatur posisi, lokasi dan kualitas atomisasi cairan. Perbandingan waktu injeksi air yang berbeda dan lokasi injektor (satu dekat dengan pintu masuk intake dan yang lainnya dekat dengan katup masuk) dengan simulasi 3D, menunjukkan bahwa lebih banyak tetesan air cair yang terperangkap di dalam silinder dengan injektor dekat dengan katup masuk [9]. Hal ini menunjukan bahwa besar kecilnya uap air yang dihasilkan mempengaruhi hasil emisi gas buang yang berarti penggunaan nozel atau injektor dengan lubang yang kecil menjadi pilihan yang baik.

Dari beberapa penelitian yang dilakukan sebelumnya telah menunjukan penurunan emisi gas buang dan konsumsi bahan bakar dengan menggunakan system injeksi air. Penelitian juga dilakukan dengan menggunakan mesin bensin maupun mesin diesel serta menggunakan system injeksi langsung ataupun tidak langsung. Namun dengan penggunaan rasio injeksi air dengan bahan bakar yang tidak tepat dapat membuat beberapa gas buang meningkat. Hal ini karena kesulitan penguapan pada air pada saat injeksi dan injeksi air dapat menyebabkan terjadinya karat pada beberapa komponen mesin.

Oleh karena itu untuk mengatasi kesulitan penguapan air dan menghindari terjadinya karat pada beberapa komponen mesin maka pada penelitian ini digunakan campuran methanol atau etanol dengan rasio yang bervariasi. Sistem injeksi dengan campuran air/methanol dan air/etanol ini juga diharapkan dapat memaksimalkan konsumsi bahan bakar dengan menempatkan injektor diposisi yang tepat. Maka pada penelitian ini menempatan injektor air diposisi intake manifold dan dengan injeksi campuran yang tepat diharapkan dapat menurunkan emisi gas buang dan konsumsi bahan bakar.

\section{METODE PENELITIAN}

Metode yang digunakan adalah metode eksperimen. Metode penelitian eksperimen dapat diartikan sebagai metode penelitian yang digunakan untuk mencari pengaruh perlakuan tertentu terhadap yang lain dalam kondisi yang terkendalikan [12]. Dimana pada metode ini akan menguji konsumsi bahan bakar dan emisi gas buang sepeda motor yang menggunakan sistem injeksi air/metanol dan air/etanol dengan jumlah persentase campuran yang berbeda.
Penelitian ini dilakukan di AHASS tempat service resmi sepeda motor untuk mengambil sampel emisi gas buang pada tangga 18 Mei 2019. Pengambilan data konsumsi bahan bakar dilakukan dengan uji jalan dimana pengujian dilakukan sesuai kondisi nyata jalan pada tanggal 25 dan 26 Mei 2019.

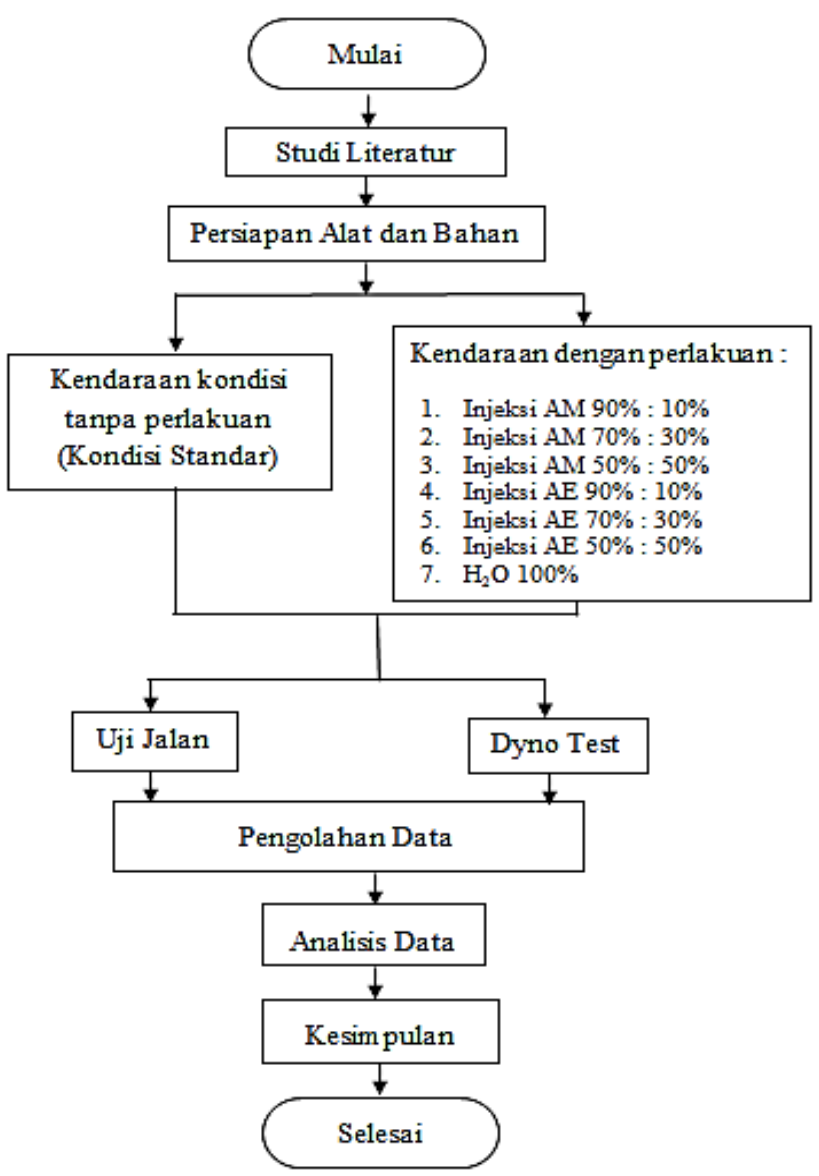

Gambar 1. Skema penelitian

Variabel bebas dalam penelitian ini adalah sistem injeksi campuran air/metanol dan air/etanol dengan perbandingan campuran bervariasi yang sudah ditentukan sebelumnya. Sedangkan variabel terikat pada penelitian ini adalah konsumsi bahan bakar dan emisi gas buang yang dihasilkan berupa gas $\mathrm{HC}, \mathrm{CO}, \mathrm{CO}_{2}$ dan $\mathrm{O}_{2}$.

\section{A. Alat dan Bahan}

Beberapa alat yang digunakan dalam penelitian ini adalah gas analyzer HG-520 yang berfungsi untuk pengambilan data emisi gas buang diantaranya gas $\mathrm{HC}$, $\mathrm{CO}, \mathrm{CO}_{2}$ dan $\mathrm{O}_{2}$. Kemudian untuk pengambilan data konsumsi bahan bakar digunakan gelas ukur untuk menghitung konsumsi bahan bakar sebelum uji coba dan sesudah uji coba.

Pada penelitian ini bahan bakar utama kendaraan yang digunakan adalah bahan bakar premium, sedangkan bahan bakar metanol dan etanol digunakan sebagai bahan bakar tambahan yang dicampurkan dengan $\mathrm{H}_{2} \mathrm{O}$ dengan perbandingan yang sudah ditentukan sebelumnya. Bahan campuran yang 
digunakan untuk mencampur metanol dan etanol adalah $\mathrm{H}_{2} \mathrm{O}$ atau air murni yang hanya mengandung hidrogen dan oksigen. Hal ini bertujuan untuk menghindari terjadinya karat jika menggunakan air yang mengandung mineral dan lainnya.

Berikut adalah tabel data bahan bakar yang digunakan baik sebagai bahan bakar utama atau bahan bakar campuran dalam penelitian ini.

Tabel 1. Perbandingan data bahan bakar [13]

\begin{tabular}{|c|c|c|c|}
\hline Properties & Gasoline & Methanol & Ethanol \\
\hline $\begin{array}{l}\text { Chemical } \\
\text { Formula }\end{array}$ & $\mathrm{C}_{8} \mathrm{H}_{18}$ & $\mathrm{CH}_{3} \mathrm{OH}$ & $\mathrm{C}_{2} \mathrm{H}_{5} \mathrm{OH}$ \\
\hline $\begin{array}{c}\text { Molecural } \\
\text { Weight }(\mathrm{g} / \mathrm{mol})\end{array}$ & $95-120$ & 46,07 & 32,04 \\
\hline $\begin{array}{c}\text { Density }(\mathrm{g} / \mathrm{cm} 3 \\
\left.\text { at } 20^{\circ} \mathrm{C}\right)\end{array}$ & $0.72-0.76$ & 0.790 & 0.792 \\
\hline $\begin{array}{c}\text { Latent heating } \\
\text { value }(\mathrm{kJ} / \mathrm{kg})\end{array}$ & 44300 & 26900 & 20100 \\
\hline $\begin{array}{c}\text { Stoichiometric } \\
\text { air/fuel ratio }\end{array}$ & 14.6 & 9 & 6,46 \\
\hline Oxygen $(\% w t)$ & - & 34.73 & 49.94 \\
\hline $\begin{array}{c}\text { Research octane } \\
\text { number }\end{array}$ & 95 & 108.6 & 108.7 \\
\hline $\begin{array}{c}\text { Motor octane } \\
\text { number }\end{array}$ & 85 & 89.7 & 88.6 \\
\hline Auto-ignition & & & \\
\hline $\begin{array}{c}\text { temperature } \\
\left({ }^{\circ} \mathrm{C}\right)\end{array}$ & $228-470$ & 363 & 455 \\
\hline $\begin{array}{c}\text { Boiling point } \\
\left({ }^{\circ} \mathrm{C}\right)\end{array}$ & $27-225$ & 78.3 & 64.5 \\
\hline $\begin{array}{c}\text { Vapor pressure } \\
\left(\mathrm{kPa} \text { at } 20^{\circ} \mathrm{C}\right)\end{array}$ & $45-90$ & 5.9 & 12.8 \\
\hline $\begin{array}{c}\text { Heat of } \\
\text { vaporization } \\
(\mathrm{kJ} / \mathrm{kg})\end{array}$ & 349 & 923 & 1178 \\
\hline $\begin{array}{c}\text { Flammable } \\
\text { Limits (\% vol.) }\end{array}$ & $1.4-7.6$ & $3.5-15$ & $5.5-36.5$ \\
\hline
\end{tabular}

Pada tabel 1 dapat terlihat perbandingan data bahan bakar utama dan campuran yang akan digunakan. Research Octane Number (RON) premium lebih rendah dibandingkan metanol dan etanol. Hal ini menguntungkan proses penguapan campuran dan untuk menghindari terjadinya knocking. Etanol yang digunakan pada penelitian ini menggunakan kadar 96\% sedangkan metanol yang digunakan dengan kadar $100 \%$.

Perbandingan injeksi tambahan air/metanol atau air/etanol yaitu dengan perbandingan Air 90\% : Metanol 10\% (AM10), Air 70\% : Metanol 30\% (AM30), Air 50\% : Etanol 50\% (AM50), Air 90\% : Etanol 10\% (AE10), Air 70\% : Etanol 30\% (AE30), Air $50 \%$ : Etanol 50\% (AE50), serta air atau $\mathrm{H}_{2} \mathrm{O} \quad 100 \%$ $\left(\mathrm{H}_{2} \mathrm{O}\right)$. Volume injeksi air/metanol atau air/etanol sebesar 15\% dari volume bahan bakar yang diinjeksikan ke ruang bakar yang diukur dalam kondisi putaran 1700 RPM.

\section{B. Spesifikasi Mesin}

Penelitian ini menggunakan sepeda motor type transmisi otomatis Continuously Variable Transmission jenis kering. Mesin yang digunakan pada penelitian ini adalah jenis mesin single overhead camshaft 4 langkah dengan berpendingin udara dan silinder tunggal dengan volume silinder $110 \mathrm{cc}$. Mesin juga sudah menggunakan sistem bahan bakar injeksi dengan Electronic Control Unit.

Tabel 2. Spesifikasi mesin sepeda motor

\begin{tabular}{ccc}
\hline Nama & Jenis/Ukuran & Satuan \\
\hline Mesin & $\begin{array}{c}\text { 4 langkah, SOHC, } \\
\text { pendingin udara, ESP }\end{array}$ & - \\
Kelas & 110 & $\mathrm{~cm}^{3}$ \\
Volume Langkah & 108,2 & $\mathrm{~cm}^{3}$ \\
Diameter X & $50 \times 55,1$ & $\mathrm{~mm}$ \\
Perbandingan \\
$\begin{array}{c}\text { Kompresi } \\
\text { Kapasitas Minyak } \\
\text { Pelumas Mesin } \\
\text { Tipe Transmsi }\end{array}$ & $9,5: 1$ & - \\
Sistem Bahan Bakar & 0,7 & liter \\
\hline
\end{tabular}

C. Instalasi Sistem Injeksi AM dan AE

Dari gambar 2. Menunjukan pemasangan sistem AM dan AE dilakukan dengan sedikit modifikasi pada intake manifold. Injektor tambahan dapat dilihat berada sebelum throttle valve hal ini bertujuan supaya semprotan dapat mengarah langsung ke ruang pembakaran dan memberikan waktu cairan untuk menjadi homogen dengan udara yang masuk melalui intake manifold dan akhirnya bercampur dengan bahan bakar masuk ke ruang bakar. Sedangkan injector bahan bakar berada dekat dengan katup masuk.

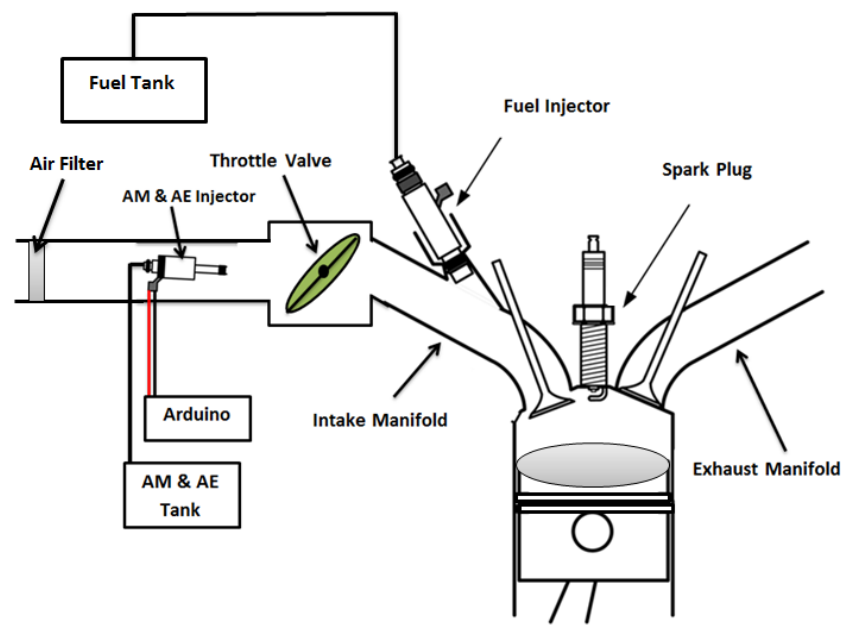

Gambar 2. Skema instalasi sistem injeksi

\section{Prosedur Penelitian}

Prosedur pada penelitian ini adalah dengan pengambilan data emisi gas buang dengan menggunakan gas analyzer HG-520 dan untuk pengambilan data konsumsi bahan bakar dilakukan uji jalan kendaraan. Proses pengambilan data berawal dari 
campuran air/metanol dan air/etanol yang berada di tangki cadangan. Di tangki cadangan terdapat pompa $\mathrm{AM}$ dan AE yang dipasang pada bagasi sepeda motor. Kemudian pompa AM dan AE yang berada pada tangki cadangan berfungsi untuk menaikkan tekanan hingga $400 \mathrm{kPa}$ berada pada kondisi yang siap ketika kunci kontak ON. Selanjutnya campuran AM dan AE diinjeksikan menggunakan injektor tambahan yang berada di intake manifold jumlah semprotan diatur oleh microcontroller unit yaitu Arduino Uno dengan cara mengirimkan sinyal PWM ke injektor sesuai dengan durasi yang sudah diatur sebelumnya. Injektor yang digunakan pada penelitian ini memiliki jumlah lubang 6 dengan diameter tiap lubang 0,13 milimeter. Sistem injeksi AM dan AE akan mulai bekerja pada saat putaran mesin mencapai $4000 \mathrm{rpm}$ dan menginjeksikan campuran AM dan AE sebanyak $15 \%$ ke ruang bakar. Injeksi AM dan AE bercampur dengan bahan bakar utama yaitu premium sebelum masuk ke ruang bakar. Proses pengambilan data emisi gas buang dilakukan berulang sebanyak 3 kali terhadap masing - masing sampel hal ini untuk mendapatkan data yang akurat. Untuk pengambilan data konsumsi bahan bakar sepeda motor dilakukan dengan cara melakukan uji jalan kendaraan dengan mengukur jumlah konsumsi bahan bakar pada kecepatan antara $40 \mathrm{~km} / \mathrm{jam}$ - $60 \mathrm{~km} / \mathrm{jam}$ pada setiap sampel uji. Kemudian dilakukan pengukuran menggunakan gelas ukur sebagai data konsumsi bahan bakar.

\section{HASIL DAN PEMBAHASAN}

Hasil penelitian yang diperoleh dari pengujian emisi gas buang dan konsumsi bahan bakar dengan menggunakan sistem komputerisasi dan diubah ke bentuk data tabel dan grafik agar dapat lebih mudah dalam proses analisis data.

\section{A. Hasil Uji Emisi}

Dari gambar 3. Data menunjukan bahwa selisih jumlah gas CO dari hasil uji beberapa sampel yang yang menggunakan injeksi AM dan AE sangat kecil, berada pada kisaran $0,05 \%$ sampai $0,08 \%$. Data nilai ini sangat jauh lebih rendah dibandingkan nilai $\mathrm{CO}$ dari hasil uji emisi kendaraan tanpa perlakuan injeksi AM dan AE.

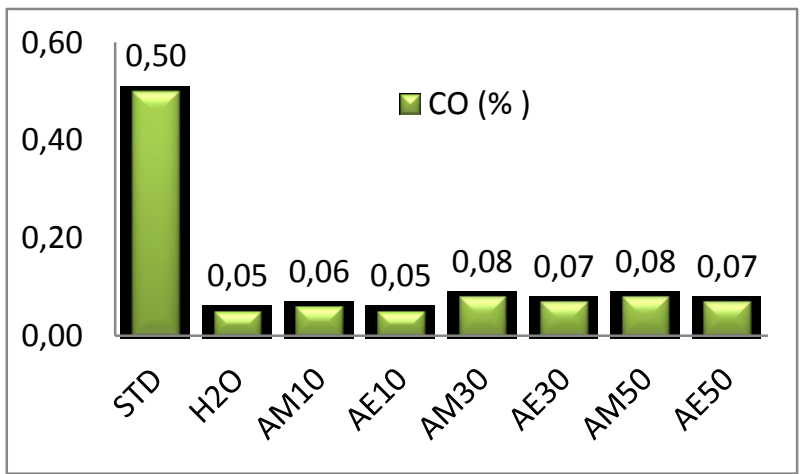

Gambar 3. Hasil uji emisi gas CO

Gambar 3 menunjukkan pengaruh sampel yang mengandung campuran $\mathrm{H}_{2} \mathrm{O}$ lebih banyak dapat menurunkan kadar gas $\mathrm{CO}$ hingga nilai terendah seperti pada sample $\mathrm{H}_{2} \mathrm{O}$ dan AE10 dengan nilai masingmasing sebesar $0,05 \%$ mengalami penurunan sebesar 90\% dibandingkan sample tanpa perlakuan injeksi AM dan AE.

Gas CO sendiri terbentuk diakibatkan dari sisa bahan bakar yang tidak terbakar dengan sempurna sehingga keluar melalui sistem pembuangan gas buang dan dapat juga diakibatkan karena campuran bahan bakar yang terlalu kaya yaitu perbandingan AFR yang tidak tepat. Melalui data hasil uji emisi ini menunjukkan bahwa bahan bakar yang dibakar dengan menggunakan sistem injeksi AM dan AE terbakar lebih sempurna dibandingkan tanpa injeksi AM dan AE.

Pada gambar 4. sampel STD yaitu sampel kendaraan tanpa perlakuan injeksi AM dan AE berada pada angka 89 ppm. Sedangkan pada kondisi sepeda motor yang mengalami perlakuan menggunakan sistem AM dan AE nilai $\mathrm{HC}$ mengalami penurunan yang signifikan dengan nilai terendah berada pada sampel AE10 sebesar 27 ppm turun sebesar $69,7 \%$. Hal ini dikarenakan dipengaruhi oleh penambahan jumlah $\mathrm{H}_{2} \mathrm{O}$ pada setiap sampel. Hal yang sama juga terjadi pada sampel-sampel lain yang menggunakan campuran metanol atau etanol mengalami penurunan kurang lebih dari 50\% dibandingkan sampel tanpa injeksi AM dan AE.

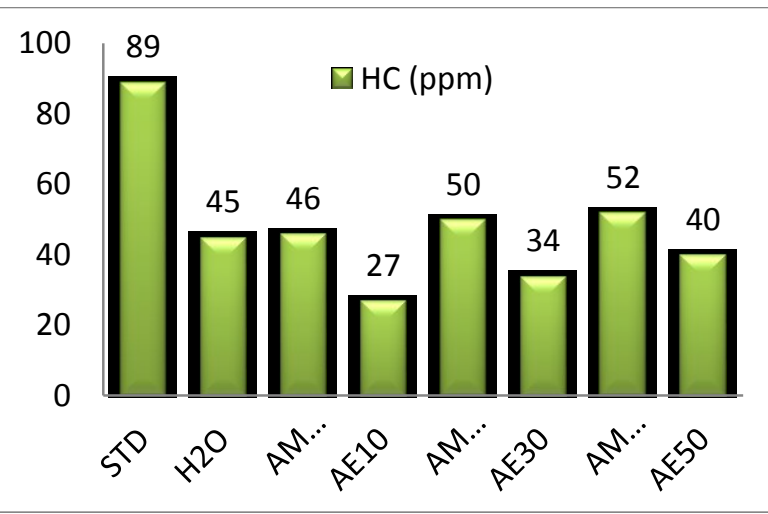

Gambar 4. Hasil uji emisi gas HC

Pada gambar 4. terlihat jumlah $\mathrm{H}_{2} \mathrm{O}$ mempengaruhi produksi gas $\mathrm{HC}$ pada pembakaran dan terlihat pada campuran etanol nilai $\mathrm{HC}$ mengalami penurunan yang sangat signifikan. Namun pada sampel $\mathrm{H}_{2} \mathrm{O}$ dengan injeksi $\mathrm{H}_{2} \mathrm{O} \quad 100 \%$ penurunan $\mathrm{HC}$ tidak sebaik campuran yang menggunakan campuran metanol atau etanol. Dari data ini dapat dilihat gas HC meningkat jika injeksi yang diberikan $100 \% \mathrm{H}_{2} \mathrm{O}$.

Gambar 5. menunjukkan gas $\mathrm{CO}_{2}$ pada sepeda motor yang tidak mengalami perlakuan yaitu sampel STD dengan hasil uji emisi $\mathrm{CO}_{2}$ berada pada nilai $13,39 \%$ hasil ini tidak jauh berbeda dengan sampel $\mathrm{H}_{2} \mathrm{O}$ yaitu 13,93 . Nilai tertinggi $\mathrm{CO}_{2}$ terdapat pada sampel AE10 dengan nilai $14,50 \%$. 


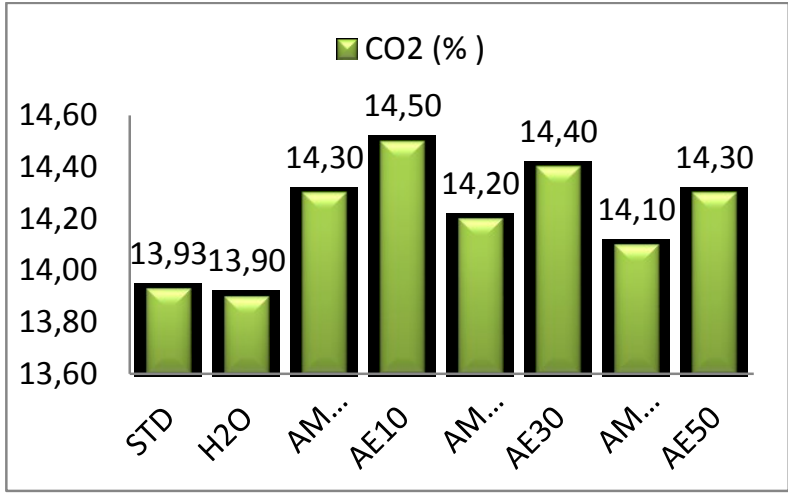

Gambar 5. Hasil uji emisi gas $\mathrm{CO}_{2}$

Dari gambar 5. kita juga dapat melihat sampel AM10, AM30 dan AM50 mengalami peningkatan nilai $\mathrm{CO}_{2}$ sebesar $10 \%$ seiring penambaham air atau $\mathrm{H}_{2} \mathrm{O}$ pada sampel. Hal yang sama juga terjadi pada sampel AE10, AE30 dan AE50 mengalami peningkatan nilai $10 \%$ seiring penambaham air atau $\mathrm{H}_{2} \mathrm{O}$ pada sampel. Dengan nilai $\mathrm{CO}_{2}$ yang berada pada angka $14,50 \%$ menunjukkan bahwa pembakaran didalam mesin sangat baik dan semakin ideal hal ini sesuai dengan nilai AFR pada sampel AE10 berada pada angka 14,7 : 1 .

Pada gambar 6. terlihat nilai gas $\mathrm{O}_{2}$ mengalami penurunan secara signifikan ketika menggunakan sistem injeksi $\mathrm{AM}$ dan $\mathrm{AE}$ dengan kisaran nilai 0,12\% sampai $0,20 \%$. Nilai ini jauh lebih rendah dari sampel tanpa injeksi AM dan AE dengan nilai 0,63\%. Nilai terendah gas $\mathrm{O}_{2}$ berada pada sampel AM50 dengan nilai $0,12 \%$. Dari hasil ini maka dapat dikatakan campuran air/metanol dan air/etanol dapat menurunkan nilai $\mathrm{O}_{2}$ yang terbuang keluar karena tidak terbakar.

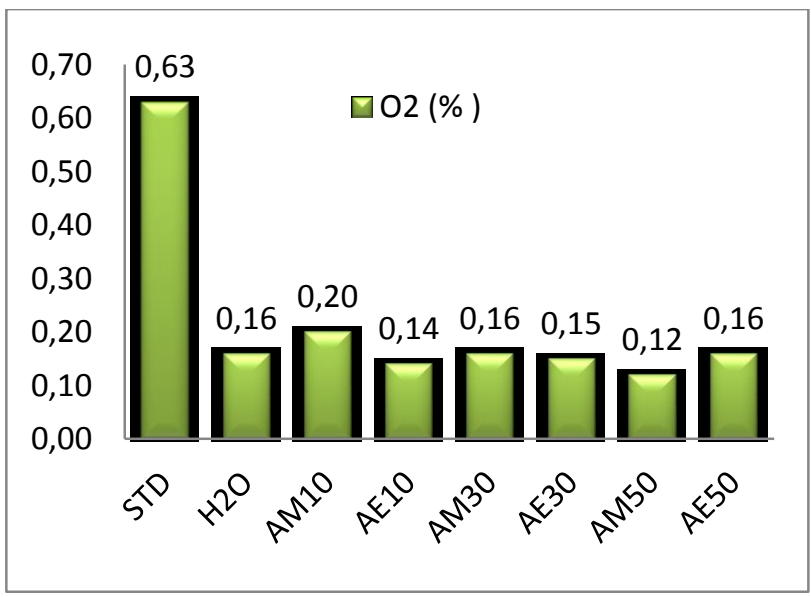

Gambar 6. Hasil uji emisi gas $\mathrm{O}_{2}$

Jika nilai gas buang $\mathrm{O}_{2}$ semakin dekat dengan nilai $0 \%$, maka proses pembakaran yang terjadi diruang bakar semakin baik karena gas $\mathrm{O}_{2}$ bereaksi dan terbakar dengan sempurna didalam ruang bakar.

\section{B. Hasil Uji Konsumsi Bahan Bakar}

Pada gambar 7. Terlihat hasil pengukuran konsumsi bahan bakar dengan melakukan uji jalan kendaraan dari berapa sampel kendaraan sepeda motor dijalan dengan bahan bakar 1 liter dan kecepatan diantara 40-60 $\mathrm{km} / \mathrm{jam}$.

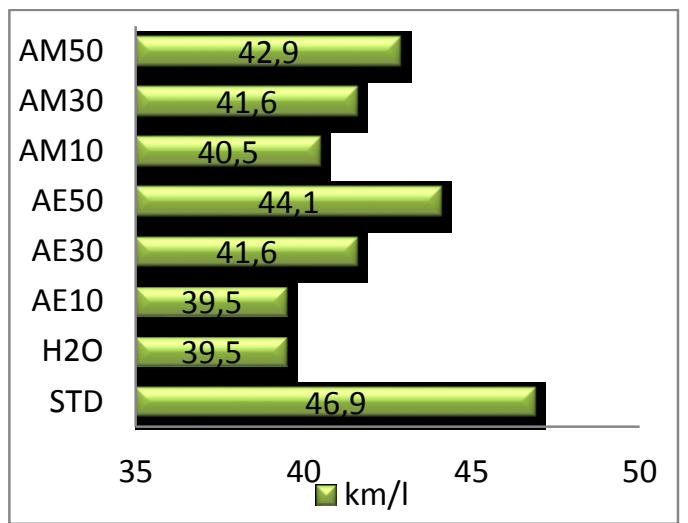

Gambar 7. Hasil uji jalan konsumsi bahan bakar

Hasil ini menunjukkan konsumsi bahan bakar terendah terdapat pada sampel STD yaitu kondisi tanpa perlakuan dengan bahan bakar 1 liter dapat menempuh jarak 46,9 $\mathrm{km}$ dan konsumsi bahan bakar tertinggi terdapat pada sampel AE10 dan $\mathrm{H}_{2} \mathrm{O}$ dengan bahan bakar 1 liter menempuh jarak 39,5 km. Dari tabel juga terlihat bahwa penambahan $\mathrm{H}_{2} \mathrm{O}$ pada setiap sampel dapat meningkatkan konsumsi bahan bakar pada kendaraan. Namun jika dibandingkan dengan hasil emisi gas buang $\mathrm{CO}, \mathrm{CO}_{2}, \mathrm{HC}$ dan $\mathrm{O}_{2}$ sampel AE10 mengalami penurunan signifikan dan berada diangka yang positif. Hal ini menunjukan peningkatan konsumsi bahan bakar dengan sistem injeksi AM dan AE tidak diikuti dengan peningkatan emisi gas buang yang diukur.

\section{KESIMPULAN}

1. Hasil uji emisi yang dilakukan pada kendaraan menunjukan penurunan emisi gas buang $\mathrm{CO}, \mathrm{HC}$, $\mathrm{CO}_{2}$ dan $\mathrm{O}_{2}$ yang sangat signifikan. Penurunan nilai $\mathrm{CO}$ tertinggi yaitu $90 \%$. Sampel $\mathrm{H}_{2} \mathrm{O}$ dan AE10 adalah sampel dengan nilai $\mathrm{CO}$ terendah yaitu $0,05 \%$. Penurunan nilai HC terbaik berada pada sampel AE10 dengan nilai $\mathrm{HC}=27 \mathrm{ppm}$ turun $69,7 \%$. Penurunan nilai $\mathrm{O}_{2}$ juga sangat signifikan yaitu sebesar $81 \%$ dibanding kondisi tanpa perlakuan dan nilai tertinggi $\mathrm{CO}_{2}$ terdapat pada sampel AE10 diangka 14,50\%. Secara keseluruhan hasil uji emisi yang menggunakan sistem injeksi AM dan AE mengalami hal positif terhadap gas buang yang dihasilkan oleh mesin sehingga dapat disimpulkan sistem injeksi tambahan ini mampu menurunkan emisi gas buang $\mathrm{CO}, \mathrm{CO}_{2}$ dan $\mathrm{HC}$.

2. Dari hasil pengujian jalan kendaraan terhadap konsumsi bahan bakar sampel STD memiliki konsumsi bahan bakar terendah diantara sampel sampel yang lain yaitu mampu menempuh jarak $46,9 \mathrm{~km} / \mathrm{l}$. Sedangkan pada sampel lainnya mengalami peningkatan konsumsi bahan bakar seiring bertambahnya $\mathrm{H}_{2} \mathrm{O}$ pada setiap sampel.

3. Dari data dapat dianalisis bahwa antara konsumsi bahan bakar dengan emisi gas buang dapat dilihat 
pada sampel STD adalah sampel dengan konsumsi bahan bakar paling rendah namun menghasilkan emisi gas buang yang paling tinggi. Sedangkan konsumsi bahan bakar yang menggunakan sistem injeksi AM dan AE rata-rata mengalami penurunan emisi gas buang yang sangat signifikan walaupun diikuti dengan konsumsi bahan bakar yang meningkat seiring penambahan $\mathrm{H}_{2} \mathrm{O}$ pada sampel.

4. Pada sampel AE10 adalah sampel dengan konsumsi bahan bakar paling tinggi dengan campuran $\mathrm{H}_{2} \mathrm{O}$ paling banyak yaitu $90 \%$ tetapi emisi gas buang yang dihasilkan menurun signifikan yaitu $\mathrm{CO}=90 \%, \mathrm{HC}=68,7 \%$ dan $\mathrm{O} 2=$ $43 \%$ sedangkan nilai $\mathrm{CO}_{2}=14,50 \%$. Konsumsi bahan bakar yang meningkat tidak membuat emisi gas buang juga meningkat dengan menggunakan sistem injeksi AM dan AE. Hal ini menunjukan bahwa konsumsi bahan bakar tinggi dengan menggunakan sistem injeksi tambahan tidak mempengaruhi peningkatan emisi gas buang karena pengunaan sistem injeksi tambahan membuat pembakaran menjadi lebih baik.

\section{UCAPAN TERIMA KASIH}

Ucapan terima kasih disampaikan kepada dealer resmi sepeda motor Honda yang telah memberikan dukungan tempat dalam pengambilan data emisi gas buang.

\section{REFERENSI}

[1] A. Boretti, "Water injection in directly injected turbocharged spark ignition engines," Appl. Therm. Eng., vol. 52, no. 1, pp. 62-68, 2013, doi: 10.1016/j.applthermaleng.2012.11.016.

[2] T. Denon, "injeksi air," 2016 http://www.automotive-technology.co.uk/?p=2492 (accessed Oct. 12, 2018).

[3] W. Mingrui, N. Thanh, R. Fii, and L. Jinping, "Water injection for higher engine performance and lower emissions," J. Energy Inst., vol. XXX, pp. 1-15, 2016, doi: 10.1016/j.joei.2015.12.003.

[4] F. Hoppe, M. Thewes, J. Seibel, A. Balazs, J. Scharf, and F. E. V. E. Gmbh, "Evaluation of the Potential of Water Injection for Gasoline Engines," SAE Int., 2017, doi: 10.4271/2017-24-0149.

[5] J. Kim, H. Park, C. Bae, and M. Choi, "Effects of water direct injection on the torque enhancement and fuel consumption reduction of a gasoline engine under high-load conditions," Int. J Engine Res., pp. 1-14, 2015, doi: 10.1177/1468087415613221.

[6] H. B. Durst B, Landerl C, Poggel J, Schwarz C, Kleczka W, "BMW water injection: Initial experience and future potentials," 2017.

[7] A. A. Raut and J. M. Mallikarjuna, "Effects of direct water injection and injector configurations on performance and emission characteristics of a gasoline direct injection engine: A computational fluid dynamics analysis," Int. J. Engine Res., vol. 21, no. $8, \quad$ pp. $1520-1540, \quad 2020$, doi: $10.1177 / 1468087419890418$.

[8] S. Zhu et al., "A review of water injection applied on the internal combustion engine," Energy Convers. Manag., 2019, doi: 10.1016/j.enconman.2019.01.042.

[9] F. Berni, S. Breda, A. D. Adamo, S. Fontanesi, and
G. Cantore, "Numerical Investigation on the Effects of Water / Methanol Injection as Knock Suppressor to Increase the Fuel Efficiency of a Highly Downsized GDI Engine," SAE Int., 2018, doi: 10.4271/2015-24-2499.

[10] B. Tesfa, R. Mishra, F. Gu, and A. D. Ball, "Water injection effects on the performance and emission characteristics of a CI engine operating with biodiesel," Renew. Energy, vol. 37, no. 1, pp. 333344, 2012, doi: 10.1016/j.renene.2011.06.035.

[11] M. Battistoni, C. N. Grimaldi, V. Cruccolini, G. Discepoli, and M. De Cesare, "Assessment of Port Water Injection Strategies to Control Knock in a GDI Engine through Multi-Cycle CFD Simulations," $S A E$ Tech. Pap., vol. 2017-Septe, 2017, doi: 10.4271/2017-24-0034.

[12] sugiyono, Metode Penelitian Pendidikan. 1st rev. Bandung: Alfabeta, 2009.

[13] M. Kemal, C. Sayin balki, and M. Canakci, "The effect of different alcohol fuels on the performance , emission and combustion characteristics of a gasoline engine," Fuel, vol. 115, pp. 901-906, 2014, doi: 10.1016/j.fuel.2012.09.020. 